\title{
Analysis of calls to the Mobile First-Aid Medical Services in a Brazilian capital city
}

\author{
Análise de chamadas do Serviço de Atendimento Móvel de Urgência de uma capital \\ brasileira
}

\author{
Análisis de llamadas del Servicios Médicos de Urgencia de una capital brasileña
}

\author{
Marilene Nonnemacher Luchtemberg ${ }^{1}$, Denise Elvira Pires de Pires ${ }^{1}$, Soraia Dornelles Schoeller ${ }^{1}$, Fabricio Pagani \\ Possamai $^{2}$
}

It is a documentary study to characterize Mobile First-Aid Medical Services calls that did not provide assistance in the state of Santa Catarina, SC, Brazil from 2007 to 2010. Data were collected from assistance reports, being noticed 393,912 prank phone calls to the institution. The main reason for the assistance not being provided was the removal of the victim by third parties. The others were refusal of care, the removal of the patient and incorrect address. There were significant differences $(\mathrm{p}<0.05)$ between the years under study concerning the calls received by the Mobile First-Aid Medical Services and the number of prank phone calls received in the state macro-regions. The results indicate the need of investment in health education activities, reducing costs and increasing effectiveness. It is also necessary to improve communication between Mobile First-Aid Medical Services and the other services (Military Police and Fire Brigade) reducing the number of assistance.

Descriptors: Emergency Medical Services; Health Services; Ambulances; Nursing.

Objetivou-se caracterizar as chamadas do Serviço de Atendimento Móvel de Urgência que não geraram atendimento no Estado de Santa Catarina, SC, Brasil, no período de 2007 a 2010. Estudo documental, cujos dados foram coletados de relatórios do serviço, sendo observadas 393.912 chamadas falsas (trotes). 0 principal motivo para que as saídas das equipes não resultassem em atendimento foi à remoção da vítima do local por terceiros. Os demais foram recusa do atendimento, evasão do local e endereço incorreto. Houve diferenças significativas $(p<0,05)$ entre os anos estudados, quanto às chamadas recebidas pelo serviço móvel e o número de trotes recebidos nas macrorregiões do Estado. Os resultados indicam a necessidade de investimentos em ações de educação em saúde, reduzindo custos e aumentando a resolutividade. Também é necessário melhorar a comunicação entre o serviço móvel e os demais serviços (Polícia Militar e Corpo de Bombeiros) diminuindo o número de saídas.

Descritores: Serviços Médicos de Emergência; Serviços de Saúde; Ambulâncias; Enfermagem.

El objetivo fue caracterizar las llamadas del Servicio Médico de Urgencia que no generaron atención en Santa Catarina, SC, Brasil, de 2007 a 2010. Estudio documental, cuyos datos se recogieron de los informes de servicio, siendo observadas 393.912 falsas llamadas (novatadas). El principal motivo para que las salidas de los equipos no resultasen en asistencia fue la remoción de víctimas del local por terceros. Los otros eran recusa de atención, evasión del sitio y dirección incorrecta. Hubo diferencias significativas $(\mathrm{p}<0,05)$ entre los años estudiados, cuanto a las llamadas recibidas por el servicio móvil y el número de novatadas recibidas en las macro-regiones del Estado. Los resultados indican necesidad de invertir en actividades de educación en salud para reducir costes y aumentar la resolutividad. También es necesario mejorar la comunicación entre el Servicio Médico de Urgencia y los otros servicios (Policía Militar y Bomberos) para disminuir el número de salidas. Descriptores: Servicios Médicos de Urgencia; Servicios de Salud; Ambulancias; Enfermeria.

\footnotetext{
${ }^{1}$ Universidade Federal de Santa Catarina. Florianópolis, SC, Brazil.

${ }^{2}$ Escola Superior de Criciúma. Criciúma, SC, Brazil.

Corresponding author: Denise Elvira Pires de Pires

Universidade Federal de Santa Catarina - Trindade, CEP: 88040-970 - Florianópolis, SC, Brazil. E-mail: piresdp@yahoo.com
} 


\section{Introduction}

The urgency pre-hospital assistance has as main objective to transport the patient who needs urgent care to a health unit which can supply adequate and effective assistance. Besides that, the victim must receive health and support assistance during all the transportation by trained professionals. This model improves the systems to the patient until the arrival at the hospital of reference and favors his survival facing the event ${ }^{(1)}$.

With the purpose to enhance and regulate the Mobile First-aid Medical Services in Brazil, the Health Department published decrees, the GM/MS no. 1863 which instituted the National Policy of Attention to Urgency and the one under no. 1864 which instituted the Mobile First-aid Medical Services, in 2003. In 2011, the decree GM/MS no. 1863 was revoked and substituted by decree no. 1600, which reformulated the National Policy of Attention to Urgency and instituted the Net of Attention to Urgency in the Unified Health System integrating basic attention, units of first-aid, hospital emergencies and home care $\mathrm{e}^{(2-3)}$.

The pre-hospital assistance made by the Mobile First-aid Medical Services, widely known as SAMU is run by teams of basic support and advanced support according to the orientations passed on by the medical regulations. The teams of basic support consist of drivers and nursing assistants or technicians who perform non-invasive supporting measures. The teams of advanced support consist of drivers, nurses and doctors who perform evasive procedures of ventilations and circulatory support and the transport of patient to be treated in hospitals ${ }^{(3-4)}$.

The pre-hospital assistance is expending widely in Brazil, but the system of distribution of services, ambulances as well as the number of health professionals must be improved and/or enhanced ${ }^{(5)}$.

As it is observed, such as in the expansion in the largest city in Brazil, in São Paulo, the number of assistant was 173,714 in 2003 increased to 463,893 in the year of 2012. Such increase in the number of assistance happened due to control of quality, training of employees and investments in infrastructure. These factors took the Mobile First-aid Medical Services of São Paulo to reach international levels of efficiency in the emergency assistance. There are 1,200 assistances daily, from 09 thousand calls. Its assistance central is the largest and the most modern in Latin American ${ }^{(6)}$.

Considering the magnitude of the policy and its recent implementation, it is worth evaluating the results of the work of the Mobile First-aid Medical Services, focusing on the analysis of the denouement of the assistance request. These reasons constituted a significant indicator for the evaluation of the policy of pre-hospital attention to urgencies and emergencies, once it is being implemented and expanded in the country. So, the present study had the objective to characterize the reasons of calls of the Mobile First-aid Medical Services which did not generate assistance in the state of Santa Catarina.

\section{Method}

It is a quantitative, descriptive, documental study of secondary source ${ }^{(7)}$, developed through the field information at the statistic data bank of the Mobile First-aid Medical Services of Santa Catarina. Such service had its beginning in November 2005; however the first registers began in 2006. It has eight centrals of medical regulation distributed throughout the state in the following regions: Western, Grande Florianópolis, Southern, Northern/Northeastern, Vale do Itajaí, Mid-western, Planalto Serrano and Foz do Itajaí ${ }^{(7-8)}$. This last one was implemented in January, 2008.

Considering the objective of the research, the data were collected from the registers of the data bank of the Mobile First-aid Medical Services, whose origin were the phone calls, from 2007 to 2010 .

The variables referring the yearly frequency and regional leaves which did not generate assistance were collected, as follows: removed by third parties, refusal of assistance, evasion from the venue, removal by the Fire Brigade/Military Police, inexistence of address, using his own ways of transportation and false phone calls. 
For the study the administrative division into macro-regions was used as follows: Mid-western, western, southern, Vale do Itajaí, Planalto Serrano, Grande Florianópolis, Foz do Rio Itajaí and Northern/ Northeastern.

The quantitative data were organized in the Windows Excel software and exported to the SPSS and analyzed through measures of descriptive statistics, averages and coefficients of variation. Bivariate analysis were also made, applying the chi-square statistic test $\left(\chi^{2}\right)$ for the analysis of the trend of the proportions (Linear-by-Linear Association), in a level of significance of $5 \%$, of the variables regarding the years studied.

The present study complies with the ethical criteria of Resolution no. 466/2012 of the National Council of Health, registered at the ERC under protocol no. 40514515.0.0000.5356.

\section{Results}

From 2007 to 2010, 1,353,150 calls were answered (Table 1) out of which 393,912 were prank phone calls (Table 2) and 12,670 were calls related to the other reasons presented in tables 3 and 4 .

Concerning all the Macro-regions of the state, the highest averages of calls were from the regions of the Planalto Serrano, followed by the Northern/ Northeast and Grande Florianópolis. Excepting the Mid-western region, the other regions presented a high coefficient of variation, indicating that there were dispersions in the results concerning the average. This indicates that there was a high degree of variability on the number of calls among the years of the study, thus indicating an inconstant frequency.

Table 1 - Yearly phone calls received by the Mobile First-aid Medical Services of the state and Macro-regions

\begin{tabular}{|c|c|c|c|c|c|c|c|c|}
\hline \multirow{2}{*}{ Macro-regions } & \multicolumn{4}{|c|}{ Year } & \multirow{2}{*}{ Average } & \multirow{2}{*}{ CV (\%) } & \multirow{2}{*}{$\chi^{2}(1)$} & \multirow{2}{*}{ p-value (2) } \\
\hline & 2007 & 2008 & 2009 & 2010 & & & & \\
\hline Mid-western & 25190 & 22418 & 19983 & 22453 & 22511.0 & 8.2 & 122.3 & $<0.0001$ \\
\hline Western & 31758 & 18871 & 32901 & 57742 & 35318.0 & 39.8 & 22797.8 & $<0.0001$ \\
\hline Southern & 55389 & 49906 & 36019 & 20450 & 40441.0 & 33.5 & 10589.9 & $<0.0001$ \\
\hline Vale do Itajaí & 102554 & 38830 & 33826 & 35839 & 52762.2 & 54.6 & 30069.6 & $<0.0001$ \\
\hline Planalto Serrano & 95301 & 75665 & 56706 & 45218 & 68222.5 & 27.9 & 12228.1 & $<0.0001$ \\
\hline Grande Florianópolis & 62778 & 55373 & 49547 & 49065 & 54190.7 & 10.2 & 18.52 & $<0.0001$ \\
\hline Foz Rio Itajaí & - & 46877 & 45084 & 36596 & 32139.2 & 59.0 & 43.537 & $<0.0001$ \\
\hline Northern/Northeastern & 103691 & 64256 & 26149 & 40406 & 58625.5 & 50.1 & 34117.5 & $<0.0001$ \\
\hline Total & 372970 & 372196 & 300215 & 307769 & 338287.5 & 10.2 & - & - \\
\hline
\end{tabular}

(1) Chi-square test $\left(\chi^{2}\right)$ to test the trend of the proportions; (2) Level of descriptive significance (p) of the $\chi^{2}$ test of trend of the proportions, comparing the four periods of the year 
Table 2 - Number of prank phone calls per year received by the Mobile First-aid Medical Services in the state of Santa Catarina, according to Macro-regions

\begin{tabular}{lccccccccc}
\hline \multirow{2}{*}{ Macro-regions } & \multicolumn{4}{c}{ Prank phone calls } & & & \multicolumn{3}{c}{ p-value } \\
\cline { 2 - 5 } & $\mathbf{2 0 0 7}$ & $\mathbf{2 0 0 8}$ & $\mathbf{2 0 0 9}$ & $\mathbf{2 0 1 0}$ & Average & CV (\%) & $\chi^{2}$ (1) & (2) \\
\hline Mid-western & 10158 & 6616 & 6210 & 14495 & 9369.7 & 35.6 & 22328.3 & $<0.0001$ \\
Western & 6016 & 6059 & 14074 & 8932 & 8770.2 & 37.4 & 24989.2 & $<0.0001$ \\
Southern & 25212 & 11929 & 4627 & 2075 & 10960.7 & 82.0 & 4962.0 & $<0.0001$ \\
Vale do Itajaí & 17385 & 12346 & 897 & 208 & 7709.0 & 95.7 & 7223.3 & $<0.0001$ \\
Planalto Serrano & 50219 & 42438 & 30206 & 11358 & 33555.2 & 43.7 & 1336.2 & $<0.0001$ \\
Grande Florianópolis & 6813 & 4344 & 3180 & 5 & 3585.5 & 68.3 & 559.7 & $<0.0001$ \\
Foz Rio Itajaí & - & 17001 & 8783 & 14 & 6449.5 & 109.6 & 4668.5 & $<0.0001$ \\
Northern/Northeastern & 52748 & 17674 & 1106 & 784 & 18078.0 & 117.0 & 35972.3 & $<0.0001$ \\
Total & 168551 & 118407 & 69083 & 37871 & 98478.0 & 50.4 & - & -
\end{tabular}

(1) Chi-square test $\left(\chi^{2}\right)$ to test the trend of the proportions; (2) Level of descriptive significance (p) of the $\chi^{2}$ test of trend of the proportions, comparing the four periods of the year

Table 3 - Frequency of the reasons of leaves which did not generate assistance at the Mobile First-aid Medical Service, according to the Macro-regions of the coast of the state of Santa Catarina per year of study

\begin{tabular}{|c|c|c|c|c|c|c|c|c|c|}
\hline \multirow{2}{*}{$\begin{array}{l}\text { Macro- } \\
\text { regions }\end{array}$} & \multirow{2}{*}{ Leaves which did not generate assistance } & \multirow{2}{*}{$\begin{array}{c}2007 \\
\text { n (\%) }\end{array}$} & \multirow{2}{*}{$\begin{array}{l}2008 \\
\text { n (\%) }\end{array}$} & \multirow{2}{*}{$\begin{array}{l}2009 \\
\text { n (\%) }\end{array}$} & \multirow{2}{*}{$\begin{array}{l}2010 \\
\text { n (\%) }\end{array}$} & \multirow{2}{*}{ Average } & \multirow{2}{*}{ CV (\%) } & \multirow{2}{*}{$\chi^{2}(1)$} & \multirow{2}{*}{$\begin{array}{c}\text { p-value } \\
\text { (2) }\end{array}$} \\
\hline & & & & & & & & & \\
\hline \multirow{6}{*}{ 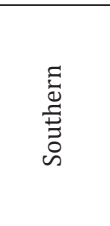 } & Removed by third parties or left on their own & $154(37.5)$ & $213(29.6)$ & $213(24.7)$ & $246(25.1)$ & 206.5 & 16,1 & 21.705 & $<0.0001^{* \downarrow}$ \\
\hline & Removed by FB/MP & $126(30.7)$ & $343(47.7)$ & $375(43.5)$ & $458(46.8)$ & 325.5 & 37.7 & 14.989 & $0.0001^{* \uparrow}$ \\
\hline & Refused assistance & $70(17.0)$ & $81(11.3)$ & $137(15.9)$ & $129(13.2)$ & 104.2 & 28.0 & 0.441 & 0.507 \\
\hline & Evaded from the venue & $37(9.0)$ & $61(8.5)$ & 89 (10.3) & $87(8.9)$ & 68.5 & 31.1 & 0.54 & 0.816 \\
\hline & Subject does not live in the address & $24(5.8)$ & $21(2.9)$ & $48(5.6)$ & $59(6.0)$ & 38.0 & 42.1 & 2.238 & 0.135 \\
\hline & Total & $411(100)$ & $719(100)$ & $862(100)$ & $979(100)$ & 742.7 & 28.6 & - & - \\
\hline \multirow{6}{*}{$\begin{array}{l}\frac{. \pi}{\pi} \\
\frac{\pi}{\pi} \\
0 \\
\frac{0}{0} \\
\frac{0}{\pi} \\
\frac{\pi}{3}\end{array}$} & Removed by third parties or left on their own & $132(37.7)$ & $31(37.8)$ & $10(21.7)$ & $219(45.4)$ & 98.0 & 85.4 & 4.78 & $0.029^{* \uparrow}$ \\
\hline & Removed by FB/MP & $80(22.9)$ & $21(25.6)$ & $18(39.1)$ & $220(45.6)$ & 84.7 & 96.6 & 49.121 & $<0.0001^{* \uparrow}$ \\
\hline & Refused assistance & $75(21.4)$ & $6(7.3)$ & $0(0.0)$ & $12(2.5)$ & 23.2 & 129.8 & 80.651 & $<0.0001^{* \downarrow}$ \\
\hline & Evaded from the venue & $41(11.7)$ & $20(24.4)$ & $12(26.1)$ & $19(3.9)$ & 23.0 & 47.1 & 18.142 & $<0.0001^{* \downarrow}$ \\
\hline & Subject does not live in the address & $22(6.3)$ & $4(4.9)$ & $6(13.0)$ & $12(2.5)$ & 11.0 & 63.6 & 6.046 & $0.014^{* \downarrow}$ \\
\hline & Total & $350(100)$ & $82(100)$ & $46(100)$ & $482(100)$ & 240.0 & 76.0 & - & - \\
\hline \multirow{6}{*}{ 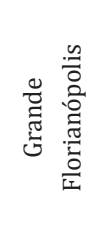 } & Removed by third parties or left on their own & $326(68.9)$ & $276(77.3)$ & $151(77.8)$ & $378(69.6)$ & 245.0 & 56.0 & 0.004 & 0.947 \\
\hline & Removed by FB/MP & $0(0.0)$ & $0(0.0)$ & $0(0.0)$ & $107(19.7)$ & 347.3 & 54.6 & 163.652 & $<0.0001^{* \uparrow}$ \\
\hline & Refused assistance & $37(7.8)$ & $28(7.8)$ & $13(6.7)$ & $11(2.0)$ & 12.3 & 50.1 & 17.614 & $<0.0001^{* \downarrow}$ \\
\hline & Evaded from the venue & $82(17.3)$ & $35(9.8)$ & $22(11.3)$ & $30(5.5)$ & 40.3 & 46.7 & 32.466 & $<0.0001^{* \downarrow}$ \\
\hline & Subject does not live in the address & $28(5.9)$ & $18(5.0)$ & $8(4.1)$ & $17(3.1)$ & 43.3 & 51.4 & 4.854 & $0.028^{* \downarrow}$ \\
\hline & Total & $473(100)$ & $357(100)$ & $194(100)$ & $543(100)$ & 391.7 & 33.7 & - & - \\
\hline \multirow{6}{*}{ 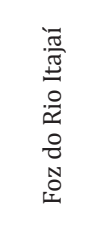 } & Removed by third parties or left on their own & $* *$ & $438(37.3)$ & $130(23.0)$ & $167(50.9)$ & 245.0 & 56.0 & 3.343 & 0.067 \\
\hline & Removed by FB/MP & $* *$ & $589(50.2)$ & $327(58.0)$ & $126(38.4)$ & 347.3 & 54.6 & 4.64 & $0.031^{* \downarrow}$ \\
\hline & Refused assistance & $* *$ & $21(1.8)$ & $9(1.6)$ & $7(2.1)$ & 12.3 & 50.1 & 0.064 & 0.800 \\
\hline & Evaded from the venue & $* *$ & $57(4.9)$ & $50(8.9)$ & $14(4.3)$ & 40.3 & 46.7 & 0.665 & 0.415 \\
\hline & Subject does not live in the address & ** & $68(5.8)$ & $48(8.5)$ & $14(4.3)$ & $43 ., 3$ & 51.4 & 0.009 & 0.922 \\
\hline & Total & $* *$ & $1173(100)$ & $564(100)$ & $328(100)$ & 688.3 & 51.7 & - & - \\
\hline \multirow{5}{*}{ 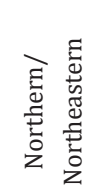 } & Removed by third parties or left on their own & $216(64.9)$ & $240(56.6)$ & $43(32.3)$ & $16(47.1)$ & 128.7 & 77.7 & 31.569 & $<0.0001^{* \downarrow}$ \\
\hline & Removed by FB/MP & $0(0.0)$ & $0(0.0)$ & $31(23.3)$ & $2(5.9)$ & 8.2 & 159.5 & 78.451 & $<0.0001^{*}$ \\
\hline & Refused assistance & $42(12.6)$ & $140(33.0)$ & $48(36.1)$ & $3(8.8)$ & 58.2 & 86.3 & 18.629 & $<0.0001^{*}$ \\
\hline & Evaded from the venue & $53(15.9)$ & $34(8.0)$ & $8(6.0)$ & $12(35.3)$ & 26.7 & 67.7 & 0.546 & 0.460 \\
\hline & Subject does not live in the address & $22(6.6)$ & $10(2.4)$ & $3(2.3)$ & $1(2.9)$ & 9.0 & 91.3 & 6.432 & $0,011^{*}$ \\
\hline
\end{tabular}

${ }^{*} \mathrm{p}<0.005 .{ }^{* \downarrow} \mathrm{p}<0.05$ with a trend of decreasing in the proportion. ${ }^{* \uparrow} \mathrm{p}<0.05$ with trend of increase in the proportion. ${ }^{* *}$ Unavailable data; $(1)$ Chi-square test $\left(\chi^{2}\right)$ to test the trend of the proportion; (2) Descriptive level of significance (p) of chi-square test $\chi^{2}$ of trend of the proportions, comparing the four periods of the year. FB= Fire Brigade and MP= Military Police 
The region of the Planalto Serrano, is the one which presents the highest number of prank phone calls regarding the other centrals of regulation, followed by Northern/Northeast and Southern region (Table 2). All the regions presented a high coefficient of variation indicating that there were dispersions in the results concerning the average, that is, the number of prank phone calls presented a great variability among the years studied.

There were significant differences $(\mathrm{p}<0.05)$ in the trend of the proportions among the years studied, concerning the calls received by the mobile service (Table 1) as well as the number of prank phone calls received in all the Macro-regions (Table 2). Such variations are expected in services which are being consolidated, where the population itself is beginning to know the services rendered by the mobile first aid medical assistance services.

Regarding the leaves which did not generate assistance and their respective reasons, the data are described in Table 3 and Table 4.
A high coefficient of variation was also observed regarding the frequency of leaves of the mobile first-aid medical service in the macro-regions of the coast and of the Planalto Serrano of the state of Santa Catarina which did not generate assistance in the variables studied, in the four years. The chi-square statistics test showed significant differences in the trend of the proportions among the years studied in all the macro-regions and in most of the reasons of leaves which did not generate assistance (table 3 and 4).

of the leaves concerning the mobile first-aid medical service which did not generate assistance, the reason 'removed by the fire brigade and military police' presented a trend of increase in the proportion in the coast of Santa Catarina, in these regions: Southern, Vale do Itajaí and Grande Florianópolis, except for the Foz do Rio Itajaí region (table 3). The reason 'removed by third parties or left on their own' presented a trend of increase in the proportion in all the regions of the Planalto Serrano of the state of Santa Catarina and in the coastal region of the Vale do Itajaí. There was a trend of decrease in the proportion in the coast of the Southern and Northeastern regions (table 3 and 4).

Table 4 - Frequency of leaves of the Mobile First-aid Medical Service in the Macro-regions of the Planalto Serrano of the state of Santa Catarina which did not generate assistance from 2007 to 2010, according to the reason and region

\begin{tabular}{|c|c|c|c|c|c|c|c|c|c|}
\hline $\begin{array}{l}\text { Macror- } \\
\text { região }\end{array}$ & Leaves which did not generate assistance & $\begin{array}{c}2007 \\
\text { n (\%) }\end{array}$ & $\begin{array}{c}2008 \\
\text { n (\%) }\end{array}$ & $\begin{array}{c}2009 \\
\text { n (\%) }\end{array}$ & $\begin{array}{c}2010 \\
\text { n (\%) }\end{array}$ & Average & CV (\%) & $\chi^{2}(1)$ & $\begin{array}{c}\text { p-valor } \\
\text { (2) }\end{array}$ \\
\hline \multirow{6}{*}{ 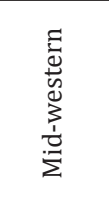 } & Removed by third parties or left on their own & $99(19.8)$ & $97(17.2)$ & $72(22.2)$ & $28(34.6)$ & 74.0 & 38.7 & 5.481 & $0,019^{* \uparrow}$ \\
\hline & Removed by FB/MP & $282(56.4)$ & $397(70.3)$ & 188(58.0) & $34(42.0)$ & 225.2 & 59.0 & 1.113 & 0,291 \\
\hline & Refused assistance & $42(8.4)$ & $12(2.1)$ & $10(3.1)$ & $5(6.2)$ & 17.2 & 84.1 & 8.865 & $0,003^{* \uparrow}$ \\
\hline & Evaded from the venue & $61(12.2)$ & $35(6.2)$ & $33(10.2)$ & $6(7.4)$ & 33.7 & 57.7 & 2.26 & 0,133 \\
\hline & Subject does not live in the address & $16(3.2)$ & $24(4.2)$ & $21(6.5)$ & $8(9.9)$ & 17.2 & 35.1 & 9.128 & $0,002^{* \uparrow}$ \\
\hline & Total & $500(100)$ & $565(100)$ & $324(100)$ & $81(100)$ & 367.5 & 51.0 & - & - \\
\hline \multirow{6}{*}{ 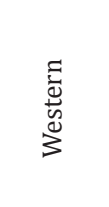 } & Removed by thir & $41(48.2)$ & $139(60.4)$ & $219(67.2)$ & $284(72.1)$ & 170.7 & 53.2 & 20.7 & $<0,0001^{* 1}$ \\
\hline & Removed by FB/MP & $0(0.0)$ & $0(0.0)$ & $0(0.0)$ & $0(0,0)$ & 0.0 & 0.0 & 0.0 & 0,0 \\
\hline & Refused assistance & $30(35.3)$ & $56(24.4)$ & $73(22.4)$ & $75(19.0)$ & 58.5 & 30.8 & 9.309 & $0,002^{* \downarrow}$ \\
\hline & Evaded from the venue & $5(5.9)$ & $25(10.9)$ & $26(8.0)$ & $28(7.1)$ & 21.0 & 44.3 & 0.59 & 0,443 \\
\hline & Subject does not live in the address & $9(10.6)$ & $10(4.4)$ & $8(2.4)$ & $7(1.8)$ & 8.5 & 13.1 & 14.117 & $<0,0001^{* \downarrow}$ \\
\hline & Total & $85(100)$ & $230(100)$ & $326(100)$ & $394(100)$ & 258.7 & 44.8 & - & - \\
\hline \multirow{6}{*}{ 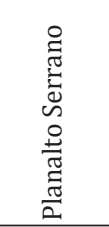 } & Removed by third parties or left on their own & $194(38.6)$ & $209(40.0)$ & $210(44.9)$ & $95(51.4)$ & 177.0 & 27.0 & 10.291 & $<0,0001^{* 1}$ \\
\hline & Removed by FB/MP & $161(32.1)$ & $111(21.2)$ & $105(22.4)$ & 55 (29.7) & 108.0 & 34.8 & 3.362 & 0,067 \\
\hline & Refused assistance & $65(13.0)$ & $119(22.8)$ & $84(18.0)$ & $13(7.0)$ & 70.2 & 54.5 & 0.554 & 0,457 \\
\hline & Evaded from the venue & $45(9.0)$ & $64(12.2)$ & $48(10.3)$ & $2(1.1)$ & 39.7 & 57.8 & 4.376 & $0,036^{* \downarrow}$ \\
\hline & Subject does not live in the address & $37(7.4)$ & $20(3.8)$ & $21(4.5)$ & $20(10.8)$ & 24.5 & 29.5 & 0.212 & 0,645 \\
\hline & Total & $502(100)$ & $523(100)$ & $468(100)$ & $185(100)$ & 419.5 & 32.6 & - & - \\
\hline
\end{tabular}

(1) Chi-square test $\left(\chi^{2}\right)$ to test the trend of the proportion;(2) Descriptive level of significance (p) of chi-square test $\chi^{2}$ of trend of the proportions, comparing the four periods of the year. $\mathrm{FB}=$ Fire Brigade and MP= Military Police 
The reasons 'refused assistance' and 'does not live in the address' presented identical profiles, with the trend of decreasing of proportion, on the coast of the region of Vale do Itajaí, Grande Florianópolis and in the Planalto Serrano in the western region. There was a trend of increase in the proportion only in the mid-western region. The reason 'evaded from the venue', that is, when the mobile first-aid medical service arrived at the venue of the event the subject was not there, presented a trend of decreasing in the proportion, on the coast of the region of Vale do Itajaí, Grande Florianópolis and in the Planaldo Serrano region (table 3 and 4).

\section{Discussion}

The data showed that the number of prank phone calls, despite their reduction along the studied period is still highly significant. The prank phone calls cause waste of resources and time of the health professionals mobilizing efforts which could be used to save lives and take care of people who really need assistance. The problem generated by the excessive number of prank phone calls is not an exception of the state of Santa Catarina. It was also found in the studies related in the work of Mobile First-aid Medical Service in the city of São Paulo. With the purpose to decrease them, the educational program 'Friends of SAMU' was implemented, developed by nurses of the Nucleus of Education of the Mobile First-aid Medical Service which guides children to use the phone numbers of the emergency services, such as: Military Police, Fire Brigade and Mobile First-aid Medical Service. The program was developed in schools of São Paulo and reduced $46 \%$ the number of prank phone calls only in the capital city of São Paulo ${ }^{(9)}$.

A study made in the United Kingdom suggests that the activities of education in health are made to decrease the number of improper calls to the services of ambulances and so reduce the unnecessary costs, as well as to improve the time of response of the assistance $^{(10)}$.
The data of the research made in the state of Santa Catarina, where the prank phone calls are constant, show that the actions of education in health can contribute to cope with the problem, decreasing possible impacts in the efficiency and efficacy of the policy of attention to urgencies and emergencies. The nursing professional can contribute in this aspect, keeping in mind that it is up to him to act in three basic dimensions: caring, educating/researching and mana$\operatorname{ging}^{(11)}$.

In England and in Wales there was an increase in the participation of the nurses in the ambulance services. Every month the contents of the calls of people who made six or more calls considered improper are evaluated by these professionals, who guide the users on the implications of the calls made improperly to the ambulance service, preventing the other health professionals to respond to other calls ${ }^{(12)}$.

In the analysis of the leaves which did not generate assistance, it was identified that among the five reasons for this occurrence, the most significant was the removal of the victim, whether by third parties, or leaving on their own, by the Fire Brigade or by the Military Police.

The removal by third parties and leaving on their own, presented a trend in the increase of the proportion in all the regions of the Planalto Serrano and on the coast in the region of the Vale do Itajaí. But, in the southern and northeastern regions there was a decrease in the proportion. The removal by the Fire Brigade or by the Military Police presents a trend of increase in the proportion on the coast of the Vale do Itajaí and Grande Florianópolis regions. These findings indicate that the services in these regions were not swift enough and that more than one public service was called at the same time.

The people can have been removed due to the delay of the service of Mobile First-aid Medical Service at the venue or to the internal difficulties and its operation. Therefore, the removal by the Fire Brigade or by the Military Police show problems in the communication between the Mobile First-aid Medical Service 
and the other services. This finding is not a peculiarity of Santa Catarina alone; the same was found in a research made in Palmas, Tocantins, Brazil, in 2009. The mentioned studied showed that the leaves which did not generate assistance were due to refusal or cancelling of assistance by the caller himself, as well as by the removal of the victim by firemen or third parties $^{(13)}$. Therefore, this fact does not only happen in Santa Catarina, being important to evaluate the event in other states, in order to contribute to the Net of Attention to Urgency.

In the analysis of the leaves which did not generate assistance, the reasons 'refused assistance' and 'does not live in the address' presented the same profiles, with the trend to decrease in the proportion on the coast, in the Vale do Itajaí, Grande Florianópolis, Planalto Serrano and western regions. The decrease of the refusal in the assistance in these regions indicates the increase of trust of the population and in the improvement of the services rendered.

Regarding the reason 'evaded from the venue' it was noticed that such fact has been reduced in the last years, presenting a trend of decrease in the proportion, on the coast of Vale do Itajaí, Grande Florianópolis and in the Planalto Serrano region. Such fact suggests that the problems by which the Mobile First-aid Medical Service was called are really important and serious or still that in those regions; the regulation is working adequately, screening the cases which really require assistance by the teams of the Mobile First-aid Medical Service.

Besides the financial costs, these leaves generate stress to the team. Under this aspect, studies made with nurses on the perception of stress describe that studies of this kind can contribute for the comprehension of stressing phenomena and that the process of work of the nursing team should be rethought, with actions turned to their management ${ }^{(14-15)}$.

The peculiarities of the regions and of the states of Brazil show the need of more studies concerning the work the Mobile First-aid Medical Service, once facing this problem is, without any doubt, a way to contribute with the process of evaluating the policy of attention to Urgencies and Emergences in the country.

\section{Conclusion}

The findings in this study show the importance to make researches which evaluate the results of the work of Mobile First-aid Medical Service and show two ways to cope with the identified problems. First, to invest in education in health, aiming at narrowing the collaboration between the population and the health services, thus contributing to reduce costs and increase resoluteness. Second, to rethink the relation among the Mobile First-aid Medical Service, Fire Brigade and the Military Police, in order to articulate efforts and adopt preventive measures to decrease the number of leaves, which do not generate assistance, thus avoiding waste of public money and loss of time of the health professionals.

\section{Collaborations}

Luchtemberg MN contributed for the planning of the project, conception, analysis and final writing of the article. Pires DEP contributed with the orientation and final revision of the article. Schoeller SD contributed with the data organization and the final revision. Possamai FP contributed with the organization of the tables, statistical analysis and final revision.

\section{References}

1. Rodriguez HCE. Atención pre hospitalaria de urgências [Internet]. 2012 [citado 2014 jan. 13]. Disponível em: http://www.aibarra.org/ Guias/1-18.htm

2. Ministério da Saúde (BR). Política Nacional de Atenção às Urgências. $3^{\underline{a}}$ ed. Brasília: Ministério da Saúde; 2006. 
3. Ministério da Saúde (BR). Portaria no 1.600, de 7 de julho de 2011. Reformula a Política Nacional de Atenção às Urgências e institui a Rede de Atenção às Urgências no Sistema Único de Saúde (SUS). [Internet]. 2011 [citado 2014 jan. 13]. Disponível em: http://bvsms.saude.gov.br/bvs/saudelegis/ gm/2011/prt1600_07_07_2011.html

4. Marques GQ, Lima MADS, Ciconet RM. Conditions treated in the mobile medical emergency services in Porto Alegre - RS. Actal Paul Enferm. 2011; 24(2):185-91.

5. Silva EAC. Aspectos históricos da implantação de um serviço de atendimento pré-hospitalar. Rev Eletr Enf. [periódico na Internet]. 2010 [citado 2014 jan. 13]; 12(3):571-7. Disponível em: www. fen.ufg.br/fen_revista/v12/n3/pdf/v12n3a23. pdf.

6. Prefeitura Municipal de São Paulo. Modernização do SAMU eleva para 463 mil o número de atendimentos feitos por ano [Internet]. 2012 [citado 2014 jan. 13]. Disponível em: http://www. prefeitura.sp.gov.br/portal/a_cidade/noticias/ index.php?p=51852.

7. Secretaria de Estado da Saúde de Santa Catarina. Superintendência de Planejamento SAMU - 192. Relatório de 2007 a 2010. [Internet]. 2011 [citado 2014 jan. 13]. Disponível em: http://samu.saude. sc.gov.br/images/estatisticas/arquivo/2006.pdf

8. Secretaria de Estado da Saúde de Santa Catarina. Serviço de Atendimento Móvel de Urgência - SAMU. Regimento interno. [Internet]. Santa Catarina; 2011. Disponível em: http://samu.saude. sc.gov.br
9. Prefeitura do Município de São Paulo. Secretaria Municipal de Saúde. Projeto Amigos do SAMU reduz em $46 \%$ número de trotes na capital. [Internet]. 2012 [citado 2014 jan. 13]. Disponível em:http://extranet.saude.prefeitura.sp.gov.br/ noticias/projeto-amigos-do-samu-reduz-em-46numero-de-trotes-na-capital.

10. Kirkby HM, Roberts LM. Inappropriate 999 calls: an online pilot survey. Emerg Med J. 2012; 29:1416.

11. Pires D. A enfermagem enquanto disciplina, profissão e trabalho. Rev Bras Enferm. 2009; 62(5):739-44.

12. Williams R. Nurses who work in the ambulance service. Emergency Nurse. 2012; 20(2):14-7.

13. Piterri JSM, Monteiro PS. Caracterização do Serviço de Atendimento Móvel de Urgência (SAMU) em Palmas-Tocantins, Brasil, em 2009. Comun Ciênc Saúde. 2010; 21(3):227-36.

14. Stumm EMF, Oliveski CC, Costa CFL, Kirchner RM. Estressores e coping vivenciados por enfermeiros em um serviço de atendimento pré-hospitalar. Cogitare Enferm. 2008; 13(1):33-43.

15. Higashi P, Simonetti JP, Carvalhaes MABL, Spiri WC, Parada CMGL. Potentially stressful situations for nurses considering the condition of accreditation of hospitals. Rev Rene. 2013; 14(6):1141-8. 